\section{Studia}

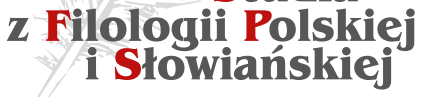

DOI: $10.11649 /$ sfps.1274
Studia z Filologii Polskiej i Słowiańskiej, 54

Warszawa 2019

Article No. 1274

\section{Citation:}

Жукова, О. Т. (2019). Деякі аспекти термінологічної деривації (на основі термінології залізничного транспорту). Studia z Filologii Polskiej i Słowiańskiej, 54. https://doi.org/10.11649 /sfps.1274

ZHukova, O. T. (2019). Deiaki aspekty terminolohichnoï deryvatsiï (na osnovi terminolohiï zaliznychnoho transportu). Studia z Filologii Polskiej i Słowiańskiej, 54. https://doi.org /10.11649/sfps.1274

Ольга Т. Жукова

\title{
Деякі аспекти термінологічної деривації (на основі термінології залізничного транспорту)
}

Розвиток наукового знання нерозривно пов’язаний зі збільшенням складу спеціальної лексики на позначення нових понять і реалій. Дослідники виділяють декілька прийомів творення термінів, а саме: термінологізацію/транстермінологізацію, термінологічну деривацію та іншомовне запозичення (Лейчик, 2007, сc. 83-84; Панько, Кочан, \& Мацюк, 1994, с. 161; Суперанская, Подольская, \& Васильева, 2003, сс. 194-219).

Проблему термінологічної деривації, зокрема творення термінів-складних слів, розглянуто в працях К. Г. Городенської, В. П. Даниленко, Н. Ф. Клименко, І. М. Кочан, А. В. Крижанівської, Д. С. Лотте, Т. І. Панько та ін.

Метою нашої статті $€$ аналіз словотвірних особливостей термінівскладних слів, які функціонують в українській залізничній терміносистемі: визначення типів дериватів за характером синтаксичних відношень, частиномовною належністю, кількістю компонентів і структурногенетичним складом та виявлення продуктивних словотвірних моделей складних слів.

Актуальність статті зумовлена тим, що дослідження терміносистеми залізничної галузі проводилися на основі російської та англійської мов

This is an Open Access article distributed under the terms of the Creative Commons Attribution 3.0 PL License (creativecommons.org/licenses/by/3.0/pl/), which permits redistribution, commercial and non-commercial, provided that the article is properly cited. (c) The Author(s) 2019.

Publisher: Institute of Slavic Studies, Polish Academy of Sciences

[Wydawca: Instytut Slawistyki Polskiej Akademii Nauk] 
(див. праці Л. А. Чернишової, О. В. Демішкевич), тоді як українські залізничні терміни досі не досліджувалися.

Матеріалом дослідження $є$ авторська вибірка термінів-складних слів галузі залізничного транспорту загальною кількістю 1851 одиниця, здійснена на матеріалі фахових перекладних словників (Боднар, Бочарова, \& Колбун, 2005; Ватуля \& Фоменко, 2000; Величко \& Величко, 1997), галузевих монографій (Бараш, 2008; Шапран, 2013), підручників (Корнійчук, Липовець, \& Шамрай, 2008a, 2008b) та періодики (Василенко, 2014).

У різних галузевих термінологіях науковці відзначають високу продуктивність термінів-складних слів (Дорошенко, 2004; Ктитарова, 2000; Нікуліна, 2004; Овсейчик, 2006).

Складним словом у мовознавстві вважається «похідне слово, утворене способом основоскладання чи словоскладання, що має не менше, ніж дві основи» (Клименко, 2004, с. 602). Поява таких термінів спричиняється ускладненням та поглибленням наукової думки, що вимагає утворення слів на позначення складних ознак або їх сукупностей, а також розширенням використання греко-латинських елементів та моделей словоскладання (Лейчик, 2007, сс. 53-54).

Компоненти складного слова об'єднуються як сурядним, так і підрядним зв’язком (Клименко, 2004, с. 602). У термінології залізничного транспорту поширення набув другий тип синтаксичних відношень, наприклад: вагоноуловлювач, колієрихтувальний, метробудування, повітронагрівач, рейкоочисний, струморозподільник, шпалоремонтний і под. У термінів-композитів ступінь пов'язаності компонентів найвищий, у юкстапозитів - найменший, «ї складники об’єднані усталеним порядком розташування» (Клименко, 2004, с. 602).

Терміни-композити в науковій літературі визначають як похідні слова, що утворилися «шляхом поєднання кількох основ у цілісну лексичну одиницю» (Горпинич, 1998, с. 126). Ця група в аналізованій вибірці $\epsilon$ найбільшою - 1577 термінів.

Утворення таких дериватів відбувається двома шляхами (Жовтобрюх \& Кулик, 1965, с. 206): 1) за допомогою сполучних голосних (інтерфіксів) o, е (є): асфальтобетон, димогарний, колієукладальний, одноколійний, штабелерозбирач, щебнеочисний тощо (972 терміни); 2) шляхом безпосереднього сполучення твірних основ слів: aвтостоп, гідростатика, електрорухомий, маслопровід, мотовоз, радіовузол та ін. (605 термінів). 
В аналізованій термінології за частиномовною належністю терміни-складні слова представлені двома лексико-граматичними групами. Більшість термінів є іменниками, як то баластоущільнювач, вододіл, гідропривод, дебектоскопія, електродепо, контейнеробудування, метропоїзд, телерегулювання і под. Складні слова-прикметники функціонують у складі термінологічних словосполучень: вантажозахватний - вантажозахватний пристрій, водовідвідний - водовідвідна споруда, локомотиворемонтний - локомотиворемонтний завод, суцільнокатаний суиільнокатане колесо тощо.

Переважна більшість термінів-композитів галузі залізничного транспорту утворена двома компонентами: антисептування, башмаконакладач, гідроредуктор, електробаластер, електрокорозія, електромонтаж, контрвантаж, пневмонасос, струмовідвід, уклонопокажчик та ін. Деякі залізничні терміни мають у своєму складі більшу кількість компонентів: вольтміліамперметр, газотурбовоз, гідроелектростанція, електровозобудування, електродинамометр, електроповітророзподільник, пародинамомашина, радіотелеграб, радіотелекерування і под.

Утворення складних слів у залізничній термінології відбувається на основі національних та іншомовних словотворчих компонентів. Серед аналізованих дериватів за походженням складових частин розрізняємо: а) залізничні терміни, утворені поєднанням питомих мовних елементів: вантажопотік, водоборотьба, вузькоколійка, деревообробка, колієукладальний, рейковіз, світловідбивач, снігоочисник тощо; б) терміни, які утворилися шляхом поєднання іншомовних словотворчих компонентів: аеродинаміка, гідромонітор, гідротурбіна, електроенергія, енергодиспетчер та ін.; в) терміни, до складу яких входять національні та іншомовні компоненти: автогальмо, високовольтний, електроживлення, електрозахист, контрвантаж, парогенератор, радіомережа і под.

Серед аналізованих залізничних термінів-композитів наявні конструкції з різними видами синтаксичних відношень: підрядним та сурядним зв'язком. Можемо виділити декілька словотвірних моделей, за якими утворюються терміни з національних компонентів на основі підрядного зв’язку. Найбільш продуктивними є такі:

1) «основа іменника + о/е + віддієслівний іменник із суфіксами -нн(я), -анн(я)»: вагонобудування, водопостачання, паливопостачання, струмознімання, шпалопросочування тощо, що використовується при творенні термінів на позначення дій та процесів; 
2) «основа іменника + о/е + прикметник»: вагонобудівний, вагономийний, вантажопідйомний, водовказівний, лавинозахисний і под., за якою утворюються терміни на позначення властивостей предметів, механізмів, що застосовуються в залізничній галузі;

3) «основа числівника або прикметника + о/е + прикметник»: багатоколійний, багатопрогоновий, важковантажний, великогабаритний, високочвидкісний, гучномовний, легкогорючий та ін., що використовується при творенні термінів на позначення якісної та кількісної ознаки;

4) «основа іменника + о/е + іменник»: вантажобагаж, вантажообіг, грозозахист, пасажиропотік, шпалозавод та ін. Ця модель застосовується для складання термінів на позначення об'єктів, предметів тощо;

5) «основа іменника + о/е + віддієслівний іменник із суфіксами -ник, -ач»: вагоноперекидач, повітроохолоджувач, повітроочисник, струмоприймач і под. Продуктивною така модель $€$ для творення назв приладів.

Менш продуктивні моделі термінів-складних слів на зразок:

1) «основа іменника + о/е + основа дієслова»: водомір, димопровід, паровідвід, повітрообмін, рівнемір тощо, яка використовується для творення термінів на позначення приладів, а також дій та процесів;

2) «основа іменника + о/е + віддієслівний іменник на -ість»: вантажомісткість, вантажонапруженість, вітростійкість, вологостійкість, пасажиромісткість та ін., за якою утворюються терміни на позначення властивостей предметів, явищ;

3) «основа іменника + о/е + віддієслівний іменник на -к(a)»: гравіємийка, каменедробарка, повітродувка тощо. Таким шляхом утворюються назви пристроїв та механізмів;

4) «займенник сам + о + іменник/прикметник»: самовентиляція, саморозвантажувач, саморушний вагон, самохідний візок і под. Ця модель продуктивна для творення назв дій, процесів та механізмів;

5) «основа числівника + и/о + основа іменника із прикметниковим суфіксом»: одноколійна лінія, двовісний візок, чотиримісне купе та ін. Такі терміни входять до складу словосполучень та використовуються на позначення предметів, механізмів тощо.

Окремо виділяємо терміни залізничного транспорту, які мають у своєму складі інтернаціональний терміноелемент (585 термінів-складних слів). Дослідники підкреслюють, що використання міжнародних терміноелементів у лексиці науки і техніки полегшує розвиток науко- 
во-технічних зв’язків між країнами (Кочан, 2004, с. 34). Терміни цієї групи утворюються за кількома моделями:

1) «національний терміноелемент + о + інтернаціональний терміноелемент»: вологоізоляція, двосекиійний, маслофільтр, парогенератор, парогідравлічний, протикорозійний, теплотехніка та ін.;

2) «інтернаціональний терміноелемент + о + національний терміноелемент»: вагоноремонтний, газотурбіна, геологорозвідка, ізоляторотримач, контейнеробудування, локомотивобудування і под.;

3) «інтернаціональний терміноелемент + національний терміноелемент»: автовізок, автоперемикач, аеровишукування, електродвигун, мотовоз, радіозв'язок, ультразвук тощо;

4) «інтернаціональний терміноелемент + інтернаціональний терміноелемент»: автодиспетчер, вольтметр, гідротурбіна, дефектоскоп, електроізоляція, мотодрезина, телетайп, топограф та ін.

Деякі науковці, зокрема I. М. Кочан (Кочан, 2004, сc. 28-29), пропонують розмежовувати компонент і терміноелемент, підкреслюючи, що компонент $€$ ширшим, родовим поняттям, і може мати декілька терміноелементів, у той час як останній $€$ поняттям видовим і не може розпадатися на інші значущі одиниці терміна. Так, наприклад, міжнародний компонент авто має чотири терміноелементи авто- із такими значеннями: 1) «автомобільний», 2) «автоматичний», 3) «свій, власний», 4) «само-» (Булыко, 2010, с. 9). Наприклад, у залізничних термінах автодрезина (залізничний візок (дрезина), який приводиться у рух за допомогою двигуна внутрішнього згорання), автомотриса (залізничний пасажирський або службовий вагон із власним двигуном) реалізується третє значення терміноелемента; у термінах автоблокування (система автоматичної сигналізації для регулювання руху поїздів), автогальмо (гальмо, яке автоматично вступає в дію при розриві поїзда), автодиспетчер (комплексна система, яка забезпечує автоматичне управління об’єктом) - друге.

Аналіз залізничної термінології показує, що міжнародні терміноелементи $є$ досить продуктивним засобом термінотворення, оскільки «короткі грецькі та латинські основи, виконуючи функцію терміноелементів, нерідко позначають ознаки, які в українській мові вимагають громіздких конструкцій складних слів та словосполучень» (Кочан, 2004, с. 35). Так, в українській залізничній термінології, окрім зазначеного вище, набули поширення універсальні міжнародні терміноелементи: аеро (гр. aer, aeros - повітря) - 
аеропоїзд, аеровишукування; гідро (гр. hydor - вода) - гідрогальмо, гідроізоляція, гідропривід, гідротурбіна; де (лат de - від, з; у значенні відміни чогось, припинення) - деблокування колій, дегазатор, деформація земляного полотна; електро (гр. electron - бурштин; у значенні «електрика») - електродвигун, електродепо, електрорухомий склад змінного струму; контр (лат. contra проти) - контррейка, контрвантаж, контрбанкет; пневмо (гр. pneuта дихання, повітря) - пневматичне обладнання, пневмонасос, пневмообдувочний пристрій; padio (лат. radio - випромінюю) - радіозв'язок станційний, радіолокачійний вимірювач координат руху поӥзда, радіопульт, радіотелекерування; теле (гр. tele - далеко) - телеавтоматика, телеграф, телемеханічне керування локомотивами, телесигналізація в системі електропостачання; термо (гр. therme - тепло, жар) - термовимикач, термоізолячія, термореле, термообробка; техно (гр. technе - майстерність) - технологічний проиес роботи станції, технологія навантажувально-розвантажувальних робіт; турбо (від лат. turbo - вихор; вказує на зв'язок із поняттям «турбіна») турбовоз, турбопоїз, турбогенератор, турбонасос.

Найменшу кількість аналізованих термінів-складних слів становить дериваційна група термінів-юкстапозитів (125 одиниць). Більшість термінів аналізованої галузі, утворених шляхом словоскладання, $\epsilon$ двокомпонентними: вагон-контейнер, мотовоз-електростанція, людино-година тощо. Поодинокі терміни мають у своєму складі три компоненти: вагон-платформа-контейнеровоз, вагон-хопер-дозатор і под.

Українські залізничні терміни, утворені шляхом словоскладання, можемо поділити на декілька тематичних груп:

1) назви транспортних засобів: вагон-колієвимірювач, вагон-хопер, дизель-поїз, дизель-тепловоз, експрес-метро, танк-паровоз;

2) назви приладів, пристроїв, об’єктів: блок-пост, вагон-дебектоскоп, ключ-жезл, контейнер-рефрижератор, мотор-генератор, напівнасипнапіввиїмка, пульт-табло, стоп-кран, телефон-апарат;

3) назви одиниць виміру: ват-година, ват-секунда, тонна-кілометр.

У складі термінології залізничного транспорту нами виявлено функціонування складних термінів, які, на думку Н. Ф. Клименко, $є$ проміжними способами творення слів «з особливостями юкстапозиції та композиції (тобто сурядним зв'язком компонентів, як у юкстапозитів, і сполучною голосною, як у композитів)» (Клименко, 2004, с. 624). Таких термінів в аналізованій вибірці 149. Вони використовуються на позначення: 
1) властивості/ознаки предмета чи дії: інженерно-геологічний - інженерно-геологічний розріз, промивально-пропарювальний - промивально-пропарювальна станція, ремонтно-екіпірувальний - ремонтноекіпірувальне депо і под.;

2) одиниць вимірювання: людино-день, пасажиро-година, пасажиро-кілометр, поїзо-кілометр тощо.

Отже, словоскладання є одним із продуктивних способів творення термінів галузі залізничного транспорту, оскільки дозволяє виражати в одному слові складне поняття на основі власне українського та/або інтернаціонального лексичного матеріалу. Окреслені моделі творення термінів-складних слів $€$ типовими для термінолексики досліджуваної галузі та становлять базу для її подальшої розбудови. Перспективним $\epsilon$ вивчення інших видів термінологічної деривації в галузі залізничного транспорту, що сприятиме систематизації й уніфікації залізничних термінів.

\section{Бібліографія}

Бараш, Ю. С. (2008). Реструктуризація залізничного транспорту Украӥни в умовах ринку (Дис. на здобуття наук. ступеня доктора екон. наук). Укр. держ. академія залізничного транспорту, Харків.

Боднар, Б. Є., Бочарова, О. О., \& Колбун, В. В. (2005). Російсько-український термінологічний словник: Вагони та вагонне господарство. Локомотиви. Дніпропетровськ: Вид-во Дніпропетр. нац. ун-ту залізн. трансп. ім. акад. В. Лазаряна.

Булыко, А. Н. (2010). Большой словарь иностранных слов (3rd ed., text rev.). Москва: Мартин.

Василенко, С. (2014). Неологістика приміських перевезень: Наземне метро. Українські залізниці, 7(13), 60-64.

Ватуля, Л. П., \& Фоменко, В. С. (2000). Російсько-украӥнський словник залізничних термінів (Ю. В. Соболев, Ed.) (2nd ed., text rev.). Київ: Транспорт України.

Величко, Г. П., \& Величко, О. М. (1997). Украӥнсько-російський словник для працівників залізничного транспорту: Понад 17 тис. термінів і термінологічних словосполучень. Київ: Транспорт України.

Горпинич, В. О. (1998). Українська словотвірна дериватологія. Дніпропетровськ: Дніпропетр. держ. ун-т.

Дорошенко, С. М. (2004). Формування та розвиток української термінологї̈ нафтогазової промисловості (Дис. на здобуття наук. ступеня канд. філол. наук). Національний педагогічний університет імені М. П. Драгоманова, Київ. 
Жовтобрюх, М. А., \& Кулик, Б. М. (1965). Курс сучасної української літературної мови (3rd ed., Pt. 1). Київ: Радянська школа.

Клименко, Н. Ф. (2004). Складне слово. In В. М. Русанівський, О. О. Тараненко, М. П. Зяблюк, et al. (Eds.), Українська мова: Енциклопедія (2nd ed., p. 602). Київ: Видавництво «Українська енциклопедія» імені М. П. Бажана.

Корнійчук, М. П., Липовець, Н. В., \& Шамрай, Д. О. (2008а). Технологія галузі і технічні засоби залізничного транспорту (2nd ed., text rev., Pt. 1). Київ: Дельта.

Корнійчук, М. П., Липовець, Н. В., \& Шамрай, Д. О. (2008b). Технологія галузі і технічні засоби залізничного транспорту (2nd ed., text rev., Pt. 2). Київ: Дельта.

Кочан, І. (2004). Динаміка і кодибікація термінів з міжнародними компонентами у сучасній українській мові. Львів: Видавничий центр ЛНУ імені Івана Франка.

Ктитарова, Н. К. (2000). Українська термінологія металургійної промисловості (Дис. на здобуття наук. ступеня канд. філол. наук). Дніпропетровський національний університет, Дніпропетровськ.

Лейчик, В. М. (2007). Терминоведение: Предмет, методы, структура (3rd ed.). Москва: Издательство ЛКИ.

Нікуліна, Н. В. (2004). Становлення сучасної украӥнської термінологічної системи автомобілебудування та ремонту транспортних засобів (Дис. на здобуття наук. ступеня канд. філол. наук). Харківський національний автомобільно-дорожній університет, Харків.

Овсейчик, С. В. (2006). Формування української екологічної термінології (Дис. на здобуття наук. ступеня канд. філол. наук). Інститут філології Київського національного університету ім. Тараса Шевченка, Київ.

Панько, Т. І., Кочан, І. М., \& Мацюк, Г. П. (1994). Українське термінознавство. Львів: Світ.

Суперанская, А. В., Подольская, А. В., \& Васильева, Н. В. (2003). Общая терминология: Bonросы теории (Т. Л. Канделаки, Ed.) (2nd ed.). Москва: Едиториал УРСС.

Шапран, Є. М. (2013). Теорія і технічні засоби адаптивного управління енергомеханічною системою тепловоза для підвищення його економічності і тягових властивостей (Дис. на здобуття наук. ступеня доктора техн. наук). Східноукраїнський національний університет імені Володимира Даля, Луганськ.

\section{Bibliography (Transliteration)}

Barash, I. S. (2008). Restrukturyzatsiia zaliznychnoho transportu Ukraïny $v$ umovakh rynku (Dys. na zdobuttia nauk. stupenia doktora ekon. nauk). Ukr. derzh. Akademiia zaliznychnoho transportu, Kharkiv.

Bodnar, B. I., Bocharova, O. O., \& Kolbun, V. V. (2005). Rosiı̌s'ko-ukrä̈ns'kyı̆ terminolohichnyı̆ slovnyk: Vahony ta vahonne hospodarstvo: Lokomotyvy. Dnipropetrovs'k: Vyd-vo Dnipropetr. nats. un-tu zalizn. transp. im. akad. V. Lazariana. 
Bulyko, A. N. (2010). Bol'shoŭ slovar' inostrannykh slov (3rd ed., text rev.). Moskva: Martin.

Doroshenko, S. M. (2004). Formuvannia ta rozvytok ukraïns'koï terminolohï naftohazovoï promyslovosti (Doctoral dissertation). Natsional'nyı̆ pedahohichnyı̌ universytet imeni M. P. Drahomanova, Kyïv.

Horpynych, V. O. (1998). Ukraïns'ka slovotvirna deryvatolohiia. Dnipropetrovs'k: Dnipropetr. derzh. un-t.

Klymenko, N. F. (2004). Skladne slovo. In V. M. Rusanivs'kyı̆, O. O. Taranenko, M. P. Ziabliuk, et al. (Eds.), Ukraïns'ka mova: Entsyklopediia (2nd ed., p. 602). Kyïv: Vydavnytstvo "Ukraïns'ka entsyklopediia" im. M. P. Bazhana.

Kochan, I. (2004). Dynamika i kodyfikatsiia terminiv z mizhnarodnymy komponentamy u suchasniı̆ ukrä̈n' kiǔ movi. L'viv: Vydavnychyı̆ tsentr LNU imeni Ivana Franka.

Korniĭchuk, M. P., Lypovets', N. V., \& Shamră̌, D. O. (2008a). Tekhnolohiia haluzi i tekhnichni zasoby zaliznychnoho transportu (2nd ed., text rev., Pt. 1). Kyïv: Del'ta.

Korniĭchuk, M. P., Lypovets', N. V., \& Shamrắ, D. O. (2008b). Tekhnolohiia haluzi i tekhnichni zasoby zaliznychnoho transportu (2nd ed., text rev., Pt. 2). Kyïv: Del'ta.

Ktytarova, N. K. (2000). Ukraïns'ka terminolohiia metalurhiünö̈ promyslovosti (Doctoral dissertation). Dnipropetrovs'kyı̆ natsional'nyı̆ universytet, Dnipropetrovs'k.

Leŭchik, V. M. (2007). Terminovedenie: Predmet, metody, struktura (3rd ed.). Moskva: Izdatel'stvo LKI.

Nikulina, N. V. (2004). Stanovlennia suchasnoï ukrä̈ns'koï terminolohichnoï systemy avtomobilebuduvannia ta remontu transportnykh zasobiv (Doctoral dissertation). Kharkivs'kyı̆ natsional'nyı̆ avtomobil'no-dorozhniı̌ universytet, Kharkiv.

Ovseĭchyk, S. V. (2006). Formuvannia ukraïns'koï ekolohichnoï terminolohï (Doctoral dissertation). Instytut filolohiï Kyïvs'koho nastional'noho universytetu im. Tarasa Shevchenka, Kyïv.

Pan'ko, T. I., Kochan, I. M., \& Matsiuk, H. P. (1994). Ukrä̈n'ke terminoznavstvo. L'viv: Svit.

Shapran, I. M. (2013). Teoriia i tekhnichni zasoby adaptyvnoho upravlinnia enerhomekhanichnoiu systemoiu teplovoza dlia pidvyshchennia ĭoho ekonomichnosti i tiahovykh vlastyvoster (Postdoctoral dissertation). Skhidnoukraïns'kyĭ natsional'nyı̆ universytet imeni Volodymyra Dalia, Luhans'k.

Superanskaia, A. V., Podol'skaia, A. V., \& Vasil'eva, N. V. (2003). Obshchaia terminologiia: Voprosy teorii (T. L. Kandelaki, Ed.) (2nd ed.). Moskva: Editorial URSS.

Vasylenko, S. (2014). Neolohistyka prymis'kykh perevezen': Nazemne metro. Ukraïns'ki zaliznytsi, 7(13), 60-64.

Vatulia, L. P., \& Fomenko, V.S. (2000). Rosǐ̌s'ko-ukraïns'kyı̆ slovnyk zaliznychnykh terminiv (I. V.Sobolev, Ed.) (2nd ed., text rev.). Kyïv: Transport Ukraïny.

Velychko, H. P., \& Velychko, O. M. (1997). Ukraïns'ko-rosiǔs'ky̆ slovnyk dlia pratsivnykiv zaliznychnoho transportu: Ponad 17 tys. terminiv i terminolohichnykh slovospoluchen'. Kyïv: Transport Ukraïny.

ZHovtobriukh, M. A., \& Kulyk, B. M. (1965). Kurs suchasnoï ukraïns'koï literaturnoï movy (3rd ed., Pt. 1). Kyïv: Radians'ka shkola. 


\title{
Selected Aspects of Terminological Derivation: A Study of Railway Transport Terminology
}

\author{
Summary
}

This article offers an analysis of patterns of compound term formation in Ukrainian railway transport terminology. The study identifies different types of derivatives according to the nature of syntactic relations between their elements, parts of speech to which they belong, and structural composition. It also provides an outline of productive derivational patterns of such compounds.

\section{Wybrane aspekty derywacji terminów na przykładzie terminologii z dziedziny transportu kolejowego}

\author{
Streszczenie
}

Artykuł przedstawia analizę modeli formowania terminów złożonych na przykładzie ukraińskiej terminologii z dziedziny transportu kolejowego. Autorka klasyfikuje omawiane przykłady pod względem relacji syntaktycznych pomiędzy ich elementami, przynależności elementów do określonych części mowy i kompozycji strukturalnej oraz przedstawia zarys modeli derywacyjnych terminów złożonych.

Keywords: term; compound word; terminological derivation; composition; juxtaposition; terminological element

Słowa kluczowe: termin; złożenie; derywacja terminów; struktura; zestawienie; element terminologiczny

Olha T. ZHukova, Donbas State Pedagogical University, Slovyansk (as in 2017)

Funding and competing interests: The author has provided no information regarding funding and competing interests. The editors have decided to publish the article without final authorisation; despite repeated attempts, the editors and the publisher have been unable to contact the author since 2017. 